\title{
Erratum to: Revision surgery after third generation autologous chondrocyte implantation in the knee
}

Thomas R. Niethammer ${ }^{1}$ - Siegfried Valentin ${ }^{1} \cdot$ Andreas Ficklscherer $^{1}$.

Mehmet F. Gülecyüz ${ }^{1}$ • Matthias F. Pietschmann ${ }^{1}$ - Peter E. Müller ${ }^{1}$

Published online: 25 June 2015

(C) SICOT aisbl 2015

Erratum to: International Orthopaedics (SICOT)

DOI 10.1007/s00264-015-2792-9

The original version of this article inadvertently contained mistake.

Author's middle names were left out. Correct presentation is given above.

The online version of the original article can be found at http://dx.doi.org/ 10.1007/s00264-015-2792-9.

Thomas R. Niethammer

thomas.niethammer@med.uni-muenchen.de

1 Department of Orthopaedic Surgery, Physical Medicine and

Rehabilitation, University Hospital of Munich (LMU),

Munich, Germany 